\title{
COMMUNICATION AND MONITORING- NECESSARY PROCESSES FOR MANAGING AND MEASURING CONFLICTS, ABSENTEEISM, FLUCTUATION AND WORK ACCIDENTS
}

\author{
Dorina Antoneta TĂNĂSESCU \\ dtanasescu2212@yahoo.fr \\ Nicoleta Valentina FLOREA \\ floreanicol@yahoo.com \\ Irina Antoaneta TĂNĂSESCU \\ a_irinaionescu@yahoo.co.uk \\ VALAHIA UNIVERSITY OF TÂRGOVIŞTE, ROMANIA
}

\begin{abstract}
In any organizations, between employees, between employees and management are inevitabily appearing conflicts, absenteeism, personnel fluctuation and work accidents (CAFA factors). To diminish the impact of these social dysfunctions, organizations must pay attention to the effective managing and monitoring using performance indicators and an effective communication process and implementing a good plan of evaluation.

In this article we propose to analyze these issues, to find solutions for their resolution, to develop an audit plan for their better understanding and assessment. We also describe some performance indicators that if they are used by organizations, they will find quick solutions for their solving and will obtain performance if they understand the causes/effects balance.
\end{abstract}

\section{Keywords}

Conflicts, absenteeism, personnel fluctuation and work accidents, communication and monitoring

\section{Introduction}

Starting from: "Communicate, communicate, and than communicate just a little bit more" [1] and "If you cannot measure something, you cannot understand it; if you cannot understand it, you cannot control it; if you cannot control it, you cannot improve it" -
Harrington I., we realize that communication and measuring processes offer an easy way to solve conflicts, to overcome absenteeism, to diminish personnel fluctuation and work accidents, and also offer a better way to understand these issues by using some performance indicators. They are inevitabily 
for any organization, but the managers if they want to find a way to solve them, first they have to detain those skills necessary to discover them on time and to develop strategies in order to diminish their influence on organization performance. The control of these social dysfunctions has the role of correcting the gap between realizations and the performance propsed standards which are geting out from strategic objectives [2]. Communicating efficiently, the firm will find measures of motivating the people, influencing their behaviour and diminishing the conflictual states.

Optimizing the communication may offer sustainable and pozitive effects organizations' activities [3]. Communication represents the artof transmitting information, ideas and attitudes and it is the key of progress through continuos and effective learning [4].

\section{Measuring Work Conflict and Its Influence on Organizational Efficiency}

Every organization and group creates a culture of conflict, ideas, values and rules that powerfully influence how its members think about and respond to conflict [5].

Conflict may take on different forms [6]:

- Individual conflict. It originates in misunderstandings among the employees for reasons that are in essence psychological. Generally, this triggers minor disturbances. It can be intrapersonal (it refers to the position of an individual in relation to himself), interpersonal (it takes place between two or more people) [7].

- Organizational conflict. The functioning of an enterprise may lead to the appearance of conflicts between two or more individuals, between two or more groups. The analysis of these conflicts needs to have in view not so much the number but rather that they concern the definition and the exercise of power in the organization. It can be between the individual and the group, intragroup, inter-group or inter-organizations [8].

- Collective conflict. It does not constitute the sum of individual conflicts; it opposes the defined categories or social classes depending on their relation to the production.

If the conflict is permanent, for the organization to be able to function, a permanent negotiation is necessary. A particular form of crisis or open conflict is the strike. Traditionally, it is defined as a collective, complete and concerted ceasing of work, in order to make some professional claims. The examination of the real forms of contemporary strike makes this traditional definition debatable: the phenomenon is not always collective; the concert is not always total; the claims go beyond the classical professional framework and need to be viewed in a broad sense.

A conflict may be competitive or related to cooperation [9], [10]:

- Competitive conflict: it occurs when the parties follow totally opposed goals. Each mistrusts the others' intentions and discredits their words. Both parties deliberately avoid the constructive dialogue and have a winlose attitude. Unavoidably, the disagreement persists and each one goes his separate way.

- Cooperative conflict: it is an experience serving best the interests of both parties, who support each other. The goal to cooperate, the trust between parties and the win-win approach are the main features of the cooperative conflict.

The existence of conflict does not necessarily lead to inefficiency. Actually, there are three perspectives on conflict:

- The positive perspective. The initiation and solution of a conflict often leads to a constructive solving of the problem, often representing stimulation for a positive change: it encourages people to solve their divergences, to get involved in the development of an ethical and equitable organization, and to be beneficial in the decision-making process.

- The negative perspective. The conflict may have serious negative effects and may hinder the efforts to attain the goals. Instead of directing the organizational resources first of all towards the attaining of the desired goals, conflict may exhaust the resources, especially time and money, and may have a negative effect on the organizational 
performances and the psychical comfort of the employees.

- The balanced perspective. The most efficient people have a balanced way of viewing conflict, admitting that it may sometimes be extremely necessary and at other times destructive.

Given their importance, conflicts are measured. Most indicators refer to strike, as a widely spread form of conflict.

In any conflict [11]:

- are set parameters for what is possible in a conflict,

- is defined what is expected,

- it is shaped the capacity to ask questions,

- are evaluated the opponents,

- it is set what is acceptable and what is not.

Out of these indicators, we shall keep in mind [12]:

- Indicators that predict the strike: multiplication of the production and leadership incidents (errors, altercations); increased number of work accidents; multiple forms of claim (petitions, claims of the personnel delegates etc.), other signs: fluctuation ratio, ratio of discards and errors, absenteeism etc.

- Strike indicators: number of work stops; number of workers involved; number of work days lost; reasons why the work ceased, costs recorded etc.

The fact that the strike is really costly for the employees and for the organization (which explains why, in general, it is a weapon of last appeal) has already been demonstrated. Yet, actually, any conflict, regardless of its nature, penalizes the organization where it occurs. Although the official statistics assure only few indications regarding the larger context in which the strikes take place, they manage, however, to provide some data on the reasons of the strikes: remuneration level; firing related to the rethinking of the organizational chart; labor union problems; work conditions control conditions; personnel hired and work repartition; firing related to discipline problems; duration - configuration of the work programme.

Strikes may be official (the labor union leaders give their consent and inform the employers in the legal time) and unofficial (initiated without the approval of the labor union leaders and without the simultaneous notification of the employer). The changes of legislation that occurred in different countries make the official strike the only type of strike benefiting of the protection of the law. Unofficial (spontaneous) strikes are no longer protected and may generate extremely serious juridical consequences.

Out of the most direct and most precisely quantifiable cost elements, we shall retain [13]:

- production loss to the detriment of the organizations, expressed either as lost turnover, or as lost profit margins;

- losses of clients that can follow the strike; beyond the loss of a sale, the enterprise may have to deal with the departure of its clients towards other providers;

- costs related to the disturbances created by the conflict. These are recorded in the enterprise where the conflict takes place but also in the enterprises upstream or downstream. They are expressed by the creation of stocks in excess or technical unemployment for the employees (or the use of subcontracting);

- costs related to production losses and to the aggravation of other problems: lower productivity, lower quality, increased absenteeism etc.;

- cost of maintaining the physical and human structure. Even when the production is completely paralyzed, the structural expenses remain;

- costs related to the degradation of the social climate associated to the triggering of the conflict;

- costs related to the decrease of the brad image of the organization in front of its partners: bankers and providers will regret the instability created and will become more prudent, and the employees will find it harder to get hired. 
Regarding the cost of conflicts, an interesting observation must be made. The cost of a conflict is not a linear function in relation to its duration.

\section{Indicators Used to Evaluate Absenteeism and Its Costs}

Absenteeism is a problem existing in organizations and referring to being absent without permission from the work place [14] and a challenge faced by the mangers in the organization [15]. Absenteeism is one of the serious problems increasingly afflicting developed societies, causing damage in the economic sphere and its solving it is beyond the immediate possibilities of our society [16]. According to the studies carried out by Mercer in 2008 on 465 organizations, it has been shown that absenteeism triggers direct costs (benefits paid to the employees) and indirect costs (a lower productivity, increased works delay, disheartening of the colleagues charged with replacing the employees who are absent), namely $9 \%$ of the total salary costs. In the USA $35 \%$ of all the absences are caused by health conditions and $65 \%$ by other causes (family problems, stress, personal needs). In the private sector, $40 \%$ of the employees are not paid for their medical leaves.

\section{Costs of absenteeism}

It is known that absenteeism has a quite low level and is not a common problem, except for some specific sectors or some specific periods of the year [17]. Although there is a great variation of the number of absences, the experts agree that an annual percentage of absenteeism under $5 \%$ is low; over $15 \%$, absenteeism can be considered as high. All the organizations should maintain a realistic standard for absenteeism of less than $5 \%$ [18]. Between the production level of an enterprise and the presence time of the employees, there is no linear relation. However, the cost of absenteeism is really important.

It is a quite difficult task to find out the costs triggered by work absenteeism [19]. The cost of absenteeism is a complex function and has three main variables [20]:
- the nature of absence,

- the number of hours which fluctuate according to individual or collective behavior,

- the ability to compensate for absence Any absence triggers [21], [22]:

- a disturbance cost: the absence of a person is the source of a lack of earning, of a production loss, of a lengthening of the production cycles, of sub-standard production and performances;

- a regularization cost: it is associated to the strategies aiming to diminish the effects of absenteeism by: use of intermediaries, supplementary hiring of other employees, payment of extra hours, of salaries and benefits and, moreover, overtime worked after the program, payment of temporary workers, payment of supervisors and managers etc. All these determine supplementary costs.

These two categories of costs are not cumulative, but complementary.

Costs may occur [23], [24], [25]:

- on an individual level - they, namely absences, affect discipline, revenues and security of position, reputation and health condition;

- on the level of the group - they affect morale, salary level, norm infringement, trigger a lower number of days off or weekends and the decrease of the productivity of the group as a whole;

- on the organizational level - they affect profit, work satisfaction, productivity, trigger increased work costs, affect relations with clients, labor unions, employees' families, organizational reputation, and relation with employees (decrease of their involvement and commitments: continual - desire to work for the organization, affective - identification with the organization and normative - he feels obliged to remain with the organization);

- On the level of the society - they affect the value attributed to the work process, to leisure time, health, loyalty to family, joy with friends and family, and the efficiency of the existing system. 


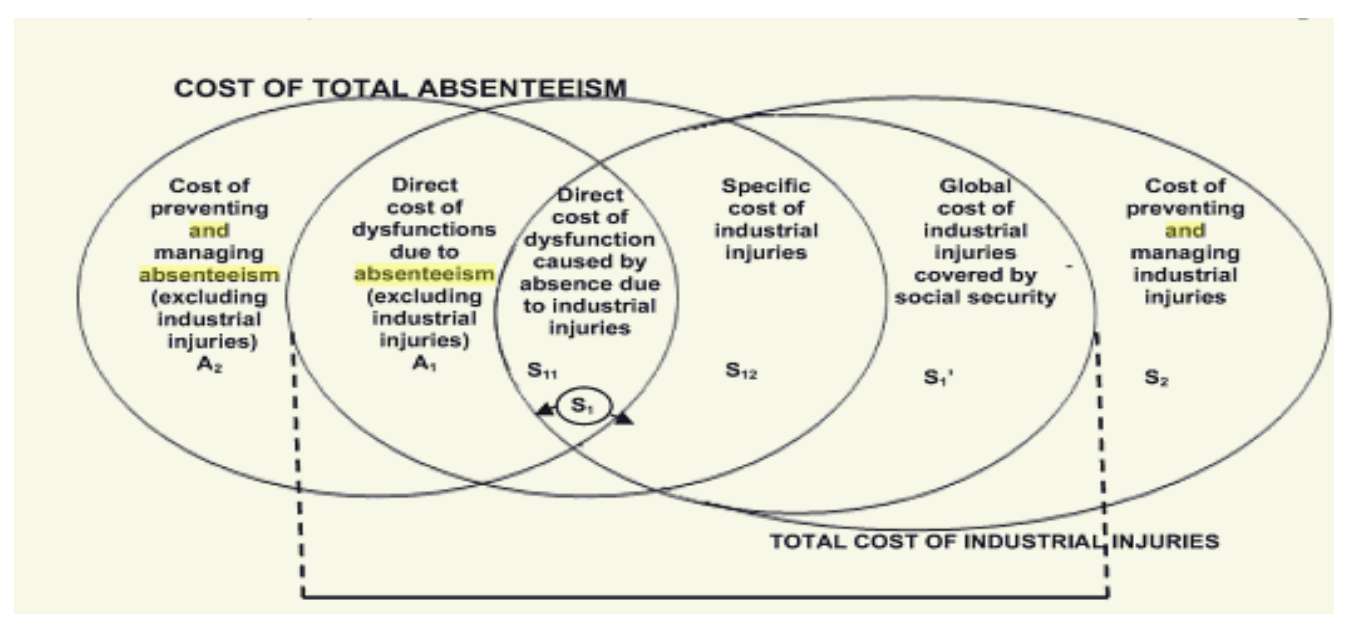

Figure no. 1 Costs from the budget and its different partial costs Source: [26].

The specialized studies have highlighted the following triggering factors [27], [28], [29]:

- gender - women, maybe less engaged in the professional activity, with less possibilities of promotion, finding it hard to conciliate, in the present stage of our society, their work life and their family life, record more absences than men;

- family size and number of children it has been noticed that the higher the number of children, the higher the absenteeism; it has also been observed that if the employee is not married, he/she tends to be absent less often;

- size of the revenues - it has been noticed that lower revenues lead to a higher absenteeism;

- degree of work satisfaction - the more satisfied at work the employees are, the less they are absent;

- proneness to disease - the more the employees are prone to disease, the more they tend to be absent;

- distance to their families - the longer the distance to their families, the higher the employees' absenteeism degree;

- age - the young (under 30 years of age) are often absent, yet for short periods of time. Older employees are absent quite little, yet for quite long periods;

- week days - absences are more numerous on Monday and Friday;

- season - absences are more numerous in January, February, March and December;
- size of enterprise - the larger the enterprise, the higher its work absenteeism;

- employees' qualification - the percentage of absences obviously, decreases, when the qualification increases;

- the geographic area and the activity sector can, in their turn, favor absenteeism.

\section{Measuring absenteeism}

The control and reduction of absenteeism begins by a continual monitoring of the statistics concerning the absences recorded, helping the manager determine the employees that are absent frequently and the departments with an excessive absenteeism [30].

Absenteeism is very hard to measure because [31]:

- the organization does not gather data on these dysfunctions, either because no adequate measurement systems are available, or because the problem is too sensitive from the managers' or the labor union's perspective;

- the organization, though collecting these data, cannot publish them or make them public, as they would affect its reputation and image;

- the literature is unable to agree on the ways of collecting the data, since no clear distinction is made between: authorized/nonauthorized absences, contractual/non-contractual absences, illness/normal absences, etc.

Methods of measuring absenteeism [32]:

- questionnaires;

- interviews;

- use of the regression function. 
Absenteeism triggers a cost that can be analyzed and measured. The measurement of absenteeism can be realized using indicators [33], [34]:

- Average duration of absences $=$ No. hours of absences (authorized and nonauthorized) during the period "P"/Average number of employees during the period "P";

- Frequency of absences $=$ No. of absences during the period "P"/Average number of employees during the period "P";

- Absenteeism ratio $=$ No. of hours of unauthorized absences/No. of hours of work realized during the period "P";

Or

- Absenteeism ratio $=$ No. of peopledays absented during a certain period / (Average number of employees) $\mathrm{x}$ (No. of working days) x 100 [35];

- Incidence ratio = no. of absences/no. of employees/day; absent;

- Inactivity ratio $=\%$ time lost by being

- Seriousness ratio $=$ average time lost/ no. of employees absent during a period. [36]:

Absenteeism has negative consequences

- direct economic loses;

- disorder in the organizations, demoralization;

- loss of prestige.

4. Personnel Fluctuation and Its Assessment

The fluctuation can be measured using specific indicators:

- Global rotation ratio:

- \% Rotation $=$ No. of collaborators departed in the year "N"/No. of collaborators in January in the year "N" x 100;

- $\%$ Rotation $=$ No. of collaborators departed in the year "N"/Average number of collaborators in the year "N" $\mathrm{x} 100$.

This indicator is calculated on subpopulations:

- workers, clerks, managers;

- administrative, technical, economic personnel;

- on geographic units;

- on gender, ancientness, nationality etc.
- Personnel stability ratio:

$-\%$ Stability of the personnel $=$ No. of collaborators whose ancientness is over " $\mathrm{X}$ " years/No. of collaborators in the year $(\mathrm{N}-\mathrm{X})$ $\mathrm{X} 100$, where " $\mathrm{X}$ " - number of years corresponding to an ancientness appreciated as significant for the organization.

Based on these indicators, one can draw different conclusions:

- if a high global rotation ratio is recorded among the population with a low ancientness, one can note problems at the integration of the new employees;

- if sensibly different results appear on subunits, for the same category, one has to have in view the eventual local problems of social relations or the impact of the environmental conditions.

To determine the reasons of the departures one can use different means:

- individual survey - during a determined period of time, the employees leaving the organization are interviewed about the reason of their departure;

- permanent questionnaires - they are sent to each employee leaving the organization. The return ratio (already a first indicator) is on average $60 \%$.

In the case of the departure of an employee, the organization may decide:

- not to replace him;

- to replace him without modifying the content of his position (with or without promotion, through internal shifting);

- to replace him and to modify the content of his position (with or without promotion, through internal shifting).

In the case of a replacement, the set of costs that needs to be considered is the same:

- recruitment and training cost (see the problems of recruitment and training);

- circulation cost - this is related to the shifting triggered by the departure of collaborators. Sometimes, the shifting may occur through geographic movement, involving departure expenses and eventual benefits;

- treasury cost - for departures, there may appear benefits set legally or conventionally; 
Win or loss of salaries, namely:

- cuts, through the departure of old collaborators and hiring of new ones, for a lower salary;

- increases, when promotions take place.

Leaving aside these costs, one can also identify specific departure costs:

- the departure of an employee is often preceded by a period of diminished productivity;

- when the departing employee may join a rival enterprise (a frequent case especially in commercial positions), one has to have in view the losses triggered by the cost of opportuneness, the losses triggered by this competition.

\section{Indicators Used to Analyze the Work Accidents}

Working accidents are sudden and sometimes violent events occuring during the execution of work leading to health damage of life of the worker [37]. Workplace accidents are the most visible manifestation of the hazards of paid work. Most work accidents are non-fatal. In everyday life may occur minor problems which affect work attendance [38].

As other types of dysfunctions, the work accidents percent may be viewed in the same time as a perturbation, but also as a factor of a bad estate for the socal system of the organization.

Accidents which affect the employees can have four types of causes [39]:

- products exintency with a high degree of danger;

- using unproper the machines and the equipments; process;

- making unproper the task of proction

- activity of employees, which are not depending of the factors mentioned below.

Generally, the work accidents:

- arise during execution of tasks, no matter the job, the position of the involved employee;

- or is a event connected directly or indirectly by the professional activity;
- affect productivity, product quality and employee morale [40].

It is in the same time an isolated case unlike the professional ilness.

To measure this phenomenon are used statistic data and indicators as:

- nb. of accidents on different categories (sex, age, groups of employees);

- material elements of the accidents;

- the frequency of fatal and non-fatal work accidents( no. of work accidents during 12 consecutive months per 100,000 workers [41];

- the incidence of the accident gravity;

- the evidence of accidents on categories of persons (age, sex, received training hours in security domain or previous accidents);

- general emenets: hour, data, day of the week, season, meteorological conditions, work conditions, etc.;

- indicators of accidents at work fatal and serious - including costs;

- severity of workplace injuries (total and mean number of days lost due to accidents at work/100,000 workers);

- incidence rate, defined as the number of accidents at work per 100,000 persons in employment [42];

- working accidents (no./100 employees/year);

- no. of working accidents requiering medical care per 100 emloyees and year [43].

6. Case Study - Developing an Audit Plan for Conflicts, Absenteeism, Fluctuation and Work Accidents (Cafa) Analysis

Starting from the model based on the development and implementation of an audit plan for the human resources management activities designed by McConnell J.H. in 2011 [44], we developed an audit plan for CAFA analysis, consisting in following steps such as Table no. 1. 


\begin{tabular}{|c|c|c|}
\hline $\begin{array}{l}\text { Steps } \\
\text { required by } \\
\text { the CAFA } \\
\text { audit } \\
\end{array}$ & General actions & Specific activities \\
\hline $\begin{array}{l}\text { l. } \\
\text { Information } \\
\text { gathering }\end{array}$ & $\begin{array}{l}\text { Addressing specific } \\
\text { questions, depending } \\
\text { on the CAFA factors; } \\
\text { Facilitating r the } \\
\text { development of an } \\
\text { information strategy. }\end{array}$ & $\begin{array}{l}\text { 1.1. Developing the necessary questionnaires to facilitate the } \\
\text { obtaining of answers } \\
\text { 1.2. Developing a database specific for information gathering } \\
\text { 1.3. Processing and interpreting the data }\end{array}$ \\
\hline $\begin{array}{l}2 . \\
\text { Information } \\
\text { evaluation }\end{array}$ & $\begin{array}{l}\text { Gathering answers; } \\
\text { Evaluating answers; } \\
\text { Measuring answers. }\end{array}$ & $\begin{array}{l}\text { 2.1. Giving a specific weight to each factor analyzed } \\
\text { 2.2. Giving a specific score } \\
\text { 2.3. Calculating a specific importance for each factor analyzed } \\
\text { 2.4. Identifying the factors with the greatest importance and } \\
\text { the smallest influence }\end{array}$ \\
\hline $\begin{array}{l}3 . \quad \text { Data } \\
\text { analysis }\end{array}$ & $\begin{array}{l}\text { Data analysis; } \\
\text { Interpretation of the } \\
\text { data obtained. }\end{array}$ & $\begin{array}{l}\text { 3.1. Comparing the data obtained to the data proposed and } \\
\text { determining the gap between the values calculated } \\
\text { 3.2. Identifying measures to minimize the gap between values } \\
\text { 3.3. Identifying the strengths and weaknesses of the system } \\
\text { under analysis }\end{array}$ \\
\hline $\begin{array}{ll}4 . & \text { Action } \\
\text { plan } & \end{array}$ & $\begin{array}{l}\text { Create an open } \\
\text { communication } \\
\text { process. } \\
\text { Develop a mediation } \\
\text { process; } \\
\text { Carrying out the } \\
\text { evaluations; } \\
\text { Calculating } \\
\text { indicators } \\
\text { performance; } \\
\text { Developing } \\
\text { measures to develop } \\
\text { the initial plan; } \\
\text { Determining strength } \\
\text { and weaknessess for } \\
\text { CAFA factors find } \\
\text { into organization; } \\
\text { Developing a Gantt } \\
\text { chart specific for } \\
\text { CAFA factors. }\end{array}$ & $\begin{array}{l}\text { 4.1. Use clear language to overcome conflicts } \\
\text { 4.2. Choose properly words, give importance of language, } \\
\text { tone of voice, body language } \\
\text { 4.3. Being precise, accord enough time to solve conflicts, } \\
\text { cooperate, offer respect, give control to situation, } \\
\text { acceptance, understanding, not-discrimination, active } \\
\text { listening, confidentiality } \\
\text { 4.4. Ask HRD, union, third part opinion and advice } \\
\text { 4.5. Use a team for mediation with different qualities, } \\
\text { experience, and knowledge use a suitable meeting space } \\
\text { for mediation } \\
\text { 4.6. Evaluating and obtaining a general view over the CAFA } \\
\text { factors present in the organization } \\
\text { 4.7. Calculating performance indicators of CAFA factors } \\
\text { found into organization } \\
\text { 4.8. Developing some measures necessary to achieve the } \\
\text { proposed standards } \\
\text { 4.9. Obtaining the necessary information to determine } \\
\text { strengths } \\
\text { 4.10. Determining measures to lead to the improvement of the } \\
\text { respective weaknesses } \\
\text { 4.11. Comparing the strengths/weaknesses in the organization } \\
\text { under analysis to those in other firms } \\
\text { 4.12. Designating specialized people, for a period of time } \\
\text { specific of the improvement of CAFA factors present in } \\
\text { the firm, a budget including the cost of these activities } \\
\text { and improvement measures (implementing a Gantt graph } \\
\text { specific for the CAFA factors). }\end{array}$ \\
\hline
\end{tabular}

Model developed by the authors 


\section{Conclusions}

Every day and in many workplaces, people are having conflicts, but not all conflicts are inherently bad. When hadled properly, conflict can actually create positive changes and new opportunities for organizations and employees [45]. That is why, sometimes conflicts should not be stopped, because often create some dissonance in order to make the work environment stimulating [46]. Some conflicts emerge from stable structure or organizations, rather than from rivalries. Conflicts can be transformed if the organization is ope to accept change and taking risks.

Without an efficient communication between employees and employers, based on trust, feedback and empathy and without an effective plan of evaluation, measuring, monitoring and control, organization will not be capable to manage efficiently the work problems as: work conflicts, absenteeism, personnel fluctuation or work accidents (CAFA factors as we nameded). Communication is a main skill of every day life, who detrmine the content estate, fulfillment; when communication is effective, the organization maintain easier the employees, and them are getting trsuing in this [47]. The research [48] is showing that communication represents the vital form of the existence of any personal and professional relationship and we add that it represents the primarly way through which people develop continual personal relationships, in order to face the continuous changing needs.

\section{References}

1. Schuttler R. et al.., Laws of communication: the intersection where leadership meets employee performance, (USA: John Wiley \& Sons, Inc., 2010): 1.

2. Duica A., Management, (Târgovişte: Editura Bibliotheca, 2008):80.

3. Minulescu, M., Comunicare organizationala, (Bucureşti: Editura Economica, 2004).

4. Flormata-Ballesteros T.M., Speech and oral communication, (Quezon City: Katha Pub.Co.Inc., 2003): 4.

5. Cloke K. and Goldsmith J., Resolving conflicts at work: eight strategies for everyone on the job, (USA: John Wiley \& Sons, Inc., 2011): 1.

6. Deaconu A. şi col., Factorul uman si performantele organizatiei, (Bucuresti: Editura ASE, 2004).

7. Duica A., 2008, cit. ed., p.258-259.

8. Ibidem, p.259-265.

9. Deaconu A. şi col., 2004, cit. ed.,

10. Duica A., 2008, cit. ed., p.275.

11. Cloke K., Goldsmith J., 2011, cit. ed., p.1.

12. Chivu I. et al., Managementul resurselor umane în IMM-uri - tendinţe contemporane, (Bucureşti: Editura Economică, 2001).

13. Deaconu A. şi col., 2004, cit. ed.

14. Saiyadain M.S., Human Resources Management, (India: Tata McGraw Hill, 2009): 457.

15. Mercer A., Basic Supervisory Management and Labour Relations, (CCH Canadian Ltd., 1999), 39.

16. Marin A.L., Sociology of organizations, (Madrid, 2012): 338.

17. Furnham A., The Psychology of Behavior at Work. The Individual in the Organization, (USA: Routledge Press, NY, 2005): 376.

18. Plunkett W.R. et al., Management. Meeting and Exceeding Customer Expectations, $10^{\text {th }}$ edition, (USA: South-Western Cengage Learning, MA, 2013): 566.

19. Furnham A., 2005, cit. ed.,p.376-377.

20. Savall H., Work and People: An Economic Evaluation of Job-Enrichment, (IAP, 2010): 217. 
21. Pell A.R., Managementul resurselor umane, (Bucureşti: Editura Curtea Veche, 2008).

22. Mathis R.L., Jackson J.H., Human Resource Management, $13^{\text {th }}$ edition, (USA: SouthWestern Cengage Learning, MA, 2011): 528.

23. Furnham A., 2005, cit. ed., p.376.

24. Saiyadain M.S., 2009, cit. ed., p.457.

25. Xiao J.J., Handbook of Consumer Finance Research, (Springer Sci \&Business Media, 2008), 382.

26. Savall H., 2010, cit. ed., p.217.

27. Deaconu A. si col., 2004, cit. ed.

28. Saiyadain M.S., 2009, cit. ed., p.457.

29. Marin A.L., 2012, cit. ed., p.338.

30. Mathis R.L., 2011, cit. ed. ,p. 527.

31. Furnham A., 2005, cit. ed., p. 376.

32. Cascio W., Boudreau J., Investing in People. Financial Impact of HR Initiatives, (USA: Pearson Edu. Inc., NY, 2011): 55.

33. Rout E.L., Omiko N., Corporate Conflict Management, (PHI Learning Ltd., 2007): 250.

34. Saiyadain M.S., 2009, cit. ed., p. 457.

35. Mathis R.L., 2011, cit. ed. ,p. 527.

36. Marin A.L., 2012, cit. ed., p.338..

37. OECD, Society at a glance 2006: OECD Social indicators, (OECD Pub., 2007): 108.

38. Zaidi A., Human resources management, (India: Excel Books, 2009): 186.

39. Pell A.R., 2008, cit. ed.

40. Hegar K., Modern human relations at work, (Cengage Learning, 2011): 488.

41. OECD, 2007, cit. ed., p.108.

42. Sirgy M.J. et al., Community quality-of-life indicators: best cases VI, (Springer Science \&Business Media, 2013): 257.

43. Alegre H., Performance indicators for water supply services, (IWA Pub., 2006): 25.

44. Florea N.V., Auditul resurselor umane, (București: Editura C.H.Beck, 2013): 9.

45. Scott V., Conflicts resolution at work for dummis, (Wiley Pub.Inc., NJ, 2010).

46. Chetkow-Yanoov B., Social work approaches to conflict resolution: making fighting obsolete, (Routledge, 2013): 88.

47. McKay M. et al., Messages. The communication skills book, (USA: New Harbinger Pub.Inc., CA, 2009): 1.

48. Wood J.T., Communication in our lives, (USA: Cengage Learning, MA, 2010): 13. 